\title{
Antagonistic and growth enhancement activities of native Pseudomonas spp. against soil and tuber-borne diseases of potato (Solanum tuberosum L.)
}

\author{
Mehi Lal ${ }^{1 *}$, Ashvani Kumar ${ }^{1}$, Sorabh Chaudhary ${ }^{1}$, R. K. Singh², Sanjeev Sharma ${ }^{3}$ and Manoj Kumar ${ }^{4}$
}

\begin{abstract}
Background: Soil and tuber-borne diseases are serious threat for potato cultivation worldwide which causes severe economical losses in terms of yield, quantity and quality. Generally, these diseases managed by chemical pesticide, are a major concern for human health and environment. Therefore, finding an eco-friendly alternative management strategies are necessary. The native bacterial isolates collected from different crops rhizosphere soil were evaluated against Rhizoctonia solani, Sclerotinia sclerotiorum, Sclerotium rolfsii and Fusarium spp and were also tested for their growth enhancement attributes on potato crop and phosphate solubilising efficiency.

Results: Based on the morphological and phenotypic characters, most of the isolates were identified as Pseudomonas spp (18 isolates). A total of twenty-two bacterial isolates were screened for bio-control activity in dual culture assay. Isolate Pf14 showed the highest mycelial inhibitory potential (ranged from 62.2 to 59.3\%) against $R$. solani, S. sclerotiorum, S. rolfsii and Fusarium spp. In sealed plate assay, Pf14 produced antifungal volatile compounds that significantly inhibited mycelial growth (ranged from $>80$ to $>50 \%$ ). Maximum reduction in fungal biomass (ranged from $>80 \%$ ) was observed in King's broth in shake liquid culture in all the pathogens. Cell-free culture filtrate of the selected isolate inhibited mycelial growth ranged from 68.9 to $42.6 \%$ of the tested pathogens with 48 -h old culture filtrate. Additionally, the isolates exhibited higher phosphorus solubilizing efficiency on PVK media. Under field conditions, talc based formulation of Pf14 showed enhanced agronomical characters and inhibits black scurf severity up to $67.59 \%$. This treatment also recorded a highest tuber yield (21.90 t/ha) with increase of $15.38 \%$ in comparison to untreated control.
\end{abstract}

Conclusion: Overall, antagonistic bacterium Pf14 can be recommended as bio fertilizers for eco-friendly management of major potato fungal diseases as well as increasing marketable yield and used as an alternative to the pesticides and chemical fertilizers.

Keywords: Antagonistic activity, Pseudomonas spp., R. solani, Fusarium spp., S. sclerotiourm, Phosphate solubilisation

\footnotetext{
*Correspondence: mehilalonline@gmail.com

1 Division of Plant Protection, ICAR-Central Potato Research Institute,

Regional Station Modipuram, Meerut, Uttar Pradesh 250 110, India

Full list of author information is available at the end of the article
}

\begin{abstract}
Background
Globally, potato (Solanum tuberosum L.) is the fourth economically important vegetable crop of food security after maize (Zea mays L.), paddy (Oryza sativa L.) and wheat (Triticum aestivum L.) (Lal et al.2019). In India, potato holds an important position among all vegetable crops, where about $25 \%$ (2.18 million ha) of total
\end{abstract}


vegetable cultivation area has devoted for potato production. There are many factors that reduce potato yields, including soil and tuber-borne diseases which play an important role; therefore control of these diseases is a very crucial.

Black scurf and/or stem canker, Fusarium wilt and/or dry rot, White mould or Sclerotinia stem rot and Sclerotium wilt are the major soil and tuber-borne diseases of potato causing considerable yield losses. Black scurf caused by Rhizoctonia solani AG-3, characterized by brown to black sclerotia on the surface of potato tubers that develop late in the crop growing season. This disease reduces the tuber quality and marketable yield up to $30 \%$ by making the scurfy appearance on the tubers (Tsror 2010). Fusarium wilt of potato is a complex disease caused by Fusarium spp. (Ommati and Sharifi 2008). Dry rot disease of potato found in both hill and plain regions in India and losses due to this pathogen may reach up to $90 \%$ in endemic areas (Sagar et al. 2011). White mould or stem rot caused by Sclerotinia sclerotiorum (Lib.) de Bary, is a serious threat in the potato production regions of different countries in the world, including India (Chaudhary et al. 2020a). Sclerotium wilt, incited by Sclerotium rolfsii (telomorph Athelia rolfsii) is an important disease of potato particularly in tropical, subtropical and the areas where temperature is sufficient high to permit the growth and survival of the pathogen (Daami-Remadi et al. 2010).

Rhizoctonia solani, S. sclerotiorum and S. rolfsii formed resting structure called sclerotia, which may survive under adverse conditions for many years and relatively inaccessible in soil. Control of sclerotia forming plant pathogens is difficult due to their genetically diverse populations, wider host range and existence in soil for a long time under various environmental conditions (Chaudhary et al. 2020b). Due to its soil and tuber-borne nature, Fusarium spp. may lead to serious problem, as wilting agent, and in stored tubers, as rot agent. These plant pathogens can be managed by various control measures such as agricultural practices, use of resistant cultivars, use of fungicides and biological control. The effectiveness of current control methods such as soil and tuber seed treatment with fungicides or crop rotations is somewhat limited (Clarkson and Whipps 2002).

Incessant use of large volumes of chemical fungicides facilitates the development of resistance in fungi, which reduces their efficacy (Apaliya et al. 2017) as well as hazardous to environment and human health. As far as there is no truly potato resistant cultivar available against these pathogens, there is an increasing demand for searching an alternative method for controlling these pathogens. Now-a-days, interest in microbial bio-agents development against plant pathogen has grown. In comparison to synthetic fungicides, bio-control is an approach for inhibiting development or spreading of the disease that is considered both safe and environment friendly (Dukare et al. 2019). Additionally, bio-agents can combat plant pathogens by multiple mode of action and development of resistance by pathogens is unlikely (Wallace et al. 2018).

A large number of antagonistic agents have been identified that effectively inhibit the soil and seed-borne pathogens under both in vitro and in vivo conditions, including Pseudomonas spp., Bacillus spp., Trichoderma spp., and Streptomyces spp. (Caulier et al. 2018). Pseudomonas spp. are widely distributed in nature, and considered as important bio-control agents and plant growth promoting rhizobacteria (PGPR). A number of PGPRs have been exploited for their antagonistic and plant growth enhancement potentials against various plant pathogens like oomycetes (Pythium spp. and Phytopthora spp.) (De Vrieze et al. 2018), fungi (Fusarium spp., Gaeumannomyces graminis, Rhizoctonia solani, etc.) (Lal et al. 2013), and some extent to bacteria (e.g. Pectobacterium carotovorum) (Ghods-Alavi et al. 2012) and nematodes (e.g. Meloidogyne spp.) (Zhai et al. 2018). Knowledge of the mechanisms of antagonism in a bio-agent is the key factor to achieve an efficient reduction of the pathogen population. Various strains follow a single mechanism and other use a combination of them. They inhibit pathogen growth through competition of nutrients and niches, siderophores secretion, as well as synthesis of antibiotics, bacteriocins and hydrolytic enzymes. They also enhance plant resistance against pathogen infection through direct interaction with the host plants, especially in the case of induced systemic resistance (ISR) (Bakker et al. 2007).

The main objectives of this study were to identify and characterize the native fluorescent Pseudomonas spp., isolated from rhizospheric soils, as a bio-control agent against major soil and tuber-borne diseases of potato and their growth enhancement effect along with phosphate solubilization potential.

\section{Methods \\ Fungal pathogens and culture conditions}

Four soil and tuber borne pathogens of potato and one (Sheath blight) from rice were used in this study. Rhizoctonia solani, Sclerotinia sclerotiorum, Sclerotium rolfsii and Fusarium spp. were isolated from infected diseased samples collected from experimental potato fields, ICAR-Central Potato Research Institute-Regional Station, Meerut, Uttar Pradesh, India. R. solani AG1-IA was collected from sheath blight infected rice plant. S. rolfsii, Fusarium spp. and $R$. solani AG1-IA were cultivated on potato dextrose agar (PDA, HiMedia) in the dark at $27 \pm 1{ }^{\circ} \mathrm{C}$. $R$. solani AG3 and S. sclerotiorum were grown 
on PDA $24 \pm 1{ }^{\circ} \mathrm{C}$ and $22 \pm 1{ }^{\circ} \mathrm{C}$, respectively. All pathogen cultures were stored in PDA slants at $4{ }^{\circ} \mathrm{C}$ for further use.

\section{Soil samples collection and bacteria isolation}

Rhizospheric soil samples were collected from rice, maize and potato fields in 3 major potato producing states of India, namely Uttar Pradesh, Punjab and Bihar, where rice-maize-potato/rice-potato cropping sequences were followed. A total of 22 rhizospheric soil samples were collected from different locations and stored at $4{ }^{\circ} \mathrm{C}$ for further processing. Soil bacteria were isolated using serial dilution technique. Briefly, $1 \mathrm{~g}$ of soil sample was evaluate the potential antagonistic activity against fungal pathogens, 2 streaks of $20 \mathrm{~mm}$ of the tested bacterial culture were made at each side of the pathogen mycelium agar disc. As control, non-inoculated NB media was streaked at each side of the pathogen mycelium agar disc. Inoculated Petri dishes were sealed with parafilm and incubated at $27 \pm 2{ }^{\circ} \mathrm{C}$ in the dark until the fungal mycelia reached the edge in the control dishes. Mycelial growth inhibition towards the bacterial inoculums was indicative of antagonistic activity. The test was repeated twice with 3 replications. The mycelial radial growth of each pathogen was measured and mycelial growth inhibition (\%) was calculated (Ji et al. 2013). The following formula was used:

\footnotetext{
Mycelial growth inhibition (\%)

$=$ Mycelial growth in control - Mycelial growth in treatment/Mycelial growth in control $\times 100$
}

suspended in $9 \mathrm{ml}$ of sterile distilled water and vortexed on a vortex mixture for $5 \mathrm{~min}$ at room temperature. The soil mixture was diluted at 1:10 ratio with sterile distilled water up to $10^{-7}$. Aliquots of $500 \mu \mathrm{l}$ from $10^{-4}$ to $10^{-7}$ were distributed in Nutrient Agar and Pseudomonas spp. specific media plates and spread with a sterile plastic rod spreader. The culture plates were incubated at $30 \pm 1{ }^{\circ} \mathrm{C}$ for $48 \mathrm{~h}$ in the dark. After incubation, the culture plates were observed under UV-trans- illuminator. The morphologically distinct and fluorescent colonies were sub-cultured onto the nutrient agar medium in separate plates to isolate single colonies. The purified bacterial isolates were conserved in LB-glycerol $(70: 30 \mathrm{v} / \mathrm{v})$ at $-80{ }^{\circ} \mathrm{C}$ for further use.

\section{Morphological characterization of bacterial isolates}

Cultural and morphological characters, such as colony colour, shapes, Gram reaction (Hucker and Conn 1923), spore formation, motility, and catalase activity (Whittenbury 1964) of all bacterial isolates were performed by following standard protocols. Bacterial motility was observed by hanging drop method described by Bertrand et al. (2001). Spore forming bacteria was determined by method described by Harrigan and MacCance (1976).

\section{In vitro screening for antagonistic activity}

Direct in vitro antagonism activities of bacterial isolates were assessed through dual culture technique on PDA medium in Petri dishes. For this purpose, bacterial inoculums were prepared in $25 \mathrm{ml}$ Nutrient Broth (NB) medium inoculated by a single colony and incubated at $30{ }^{\circ} \mathrm{C}$ and $120 \mathrm{rpm}$ for $24 \mathrm{~h}$. A $5-\mathrm{mm}$ agar disc covered with actively growing mycelium of each fungal pathogen was placed at the centre of Petri dishes separately. To

\section{Evaluation of the effect of volatile organic compounds (VOCs)}

To evaluate the antifungal effect of volatile organic compounds (VOCs) produced by bacterial isolates on fungal pathogens, mouth-to-mouth sealed plate assay previously described by Raza et al. (2016) was used. Bacterial suspensions $(100 \mathrm{ul})$ of $1 \times 10^{7} \mathrm{cfu} / \mathrm{ml}$ was spread on plates containing Nutrient Agar (NA) medium and incubated at $30{ }^{\circ} \mathrm{C}$ for $24 \mathrm{~h}$ in the dark. After incubation, the lid of each plate was replaced by a PDA plate containing an agar disc ( $5 \mathrm{~mm}$ diameter) covered with mycelium of pathogen. The pathogen containing PDA plate was placed at upper side and bacteria inoculated plate placed at lower side. Plates containing sterile distilled water without bacterial suspension served as control. All plates were sealed with a double layer of Parafilm. The sealed sets of plates were incubated at $27 \pm 2{ }^{\circ} \mathrm{C}$, and the observations were recorded at $24 \mathrm{~h}$ intervals for 3 days. The test was repeated twice with 3 replications. The mycelial growth inhibition (\%) of each pathogen was calculated according to the Trivedi et al. (2008).

\section{Quantitative evaluation of antagonism of the selected isolate in different media}

For quantitative evaluation of antagonistic activity of the screened bacterial isolate namely Pf14, 5 different broth media like, potato dextrose, nutrient, King's B, tryptone soya, and tryptone yeast extract broth were used. One $\mathrm{ml}\left(A_{600}=0.2\right)$ culture broth of the selected isolate, and a 5 -mm agar disc covered with actively growing mycelium of each fungal pathogen were co-cultured in $50 \mathrm{ml}$ different broth mediums in separate $250 \mathrm{ml}$ conical flasks. The inoculated flasks were incubated at $27 \pm 2{ }^{\circ} \mathrm{C}$ and $120 \mathrm{rpm}$ for 2 days on a rotary incubator shaker. Broth 
flasks inoculated with only fungal pathogens served as control. The test was repeated twice with 3 replications. After incubation, biomass was filtered through preweighed Whatman No. 1 filter paper and dried at $70{ }^{\circ} \mathrm{C}$ for $24 \mathrm{~h}$. The differences in dry weights between the fungal pathogens and the bacterium or the control culture (without bacteria inoculation) were recorded. Percentage (\%) reduction in fungal pathogens biomass in co-culture compared to control was calculated according to Trivedi et al. (2008).

\section{Evaluation of the effect of cell-free culture filtrates from selected isolate}

The selected isolate i.e. Pf14 was inoculated in $50 \mathrm{ml} \mathrm{NB}$ medium and grown at $30 \pm 2{ }^{\circ} \mathrm{C}$ on a rotator incubator shaker at $120 \mathrm{rpm}$. Broth culture after 24 and $48 \mathrm{~h}$ of incubation was centrifuged at 10,000 rpm for $10 \mathrm{~min}$. at $4{ }^{\circ} \mathrm{C}$ and supernatant was taken. Cell-free culture filtrate (CFCF) was obtained by passing the supernatant through $0.22 \mu \mathrm{m}$ pore size syringe filter. A 5-mm mycelium disc of each pathogen was placed in the centre of each plate. Two wells $(5 \mathrm{~mm})$ were made $3 \mathrm{~cm}$ away from the mycelium disc and aliquoted with $100 \mu \mathrm{l}$ of CFCF. Plates in which wells were aliquoted with non-inoculated NB served as control. The plates were incubated at $27 \pm 2{ }^{\circ} \mathrm{C}$ for 5 days in the dark. The test was repeated twice with 3 replications. Percent (\%) mycelial growth inhibition was calculated as described above.

\section{Evaluation of the phosphate solubilisation activity}

Bacterial isolates were evaluated for their phosphate solubilisation ability on Pikovskaya's (PVK) agar media supplemented with insoluble tri-calcium phosphate (TCP) at final concentration of $0.5 \%$. Each bacterial isolate was spot inoculated at the centre of PVK agar plates under aseptic condition. The plates were incubated at $28 \pm 2{ }^{\circ} \mathrm{C}$ for 7 days in the dark. After incubation, colony diameter and halo zone were measured for each isolate. A clear halo zone around the growing bacterial colony indicated phosphate solubilisation. Phosphate solubilisation index (SI) and solubilisation efficiency were calculated using the formula described by Edi-Premono et al. (1996): (year 2020-2021) in Randomized Block Design (RBD) with 3 replicates. Fully infested seed tubers of cv. Kufri Bahar were used for planting. Spore suspension and talc based formulation of Pf10 and Pf14 were used to evaluate their efficacy against the black scurf of potato. The infested tubers were submerged in spore suspension $\left(10^{9} \mathrm{cfu} / \mathrm{ml}\right)$ and talc based formulation (0.5\%), separately, for $1.5 \mathrm{~h}$. The shade dried treated seed tubers were planted in second week of November in a standard plot size of $9.0 \mathrm{~m}^{2}$ size. Five rows of three meters length and $60 \times 20 \mathrm{~cm}$ row $\times$ plant spacing were maintained. The crop was grown by the application of 180:80:100 kg N: P2O5:K2O per hectare and remaining other activities were followed as per standard recommended agronomic package and practices of the region.

\section{Growth enhancement activities}

The agronomical characteristics such as germination (\%) was recorded after 30 days of planting, whereas plant height $(\mathrm{cm})$, no. of stems/ plant, no. of leaves/plant and root length $(\mathrm{cm})$ were recorded after 60 days of planting, following standard procedures. Marketable tuber yield was recorded at the time of harvesting.

\section{Assessment of disease}

Disease incidence of stem canker was recorded at 35 DAP (Days after Planting) and black scurf incidence was recorded at harvesting using randomly selected 75 tubers from each plot. The tubers were washed with running tap water to remove soil and visualize clear symptoms of black scurf. These tubers were categorized as a $0-4$ scale as their coverage of tuber infection using the following scale:

0: No sclerotia

$1: 1-25 \%$ of tuber surface covered

2: $26-50 \%$ of tuber surface covered

3: $51-75 \%$ of tuber surface covered

4: $>75 \%$ of tuber surface covered

\section{Statistical analysis}

In each experiment 3 replications was maintained for

Phosphate Solubilisation Index $(\mathrm{SI})=($ Colony diameter + Halo zone diameter $) /$ Colony diameter

Phosphate Solubilisation Efficiency $(\mathrm{SE})=$ (Colony diameter - Halo zone diameter $) /$ Colony diameter $\times 100$

\section{Evaluation of antagonistic and growth enhancement potentials of Pf10 and Pf 14 under field conditions Plant materials and experimental design}

The experiments were laid down at Experimental Field Station, ICAR-Central Potato Research Institute, Regional station, Meerut, Uttar Pradesh, India during Rabi season in vitro and field studies, 4 replications were maintained. Data were statistically analyzed by one-way ANOVA and two-tailed $t$ tests using software SPSS (IBM Analytics, Armonk, NY, USA). Data were presented as mean \pm standard deviations (mean \pm SD) where appropriate. Percent data were analyzed after angular transformation and 
intergroup differences were considered to statistically significant at $P \leq 0.05$.

\section{Results}

\section{Cultural and morphological characterizations of bacterial} isolates

A total of 22 bacterial isolates were recovered from rhizospheric soil of rice, maize and potato plants collected from different location of three states of India (Table 1). On specialized medium, the bacterial colonies appeared as whitish with viscous, mucous, convex in shape, opaque, and uniformly rounded edges. Based on their morphological characteristics, 17 were short rods and Gram -ve, while 5 isolates were long rods. Five isolates, namely, Pf4, Pf7, Pf12, Pf21, and Pf22, were spore forming, while rest of the isolates were non-spore forming bacteria. Most of the isolates showed fluorescent green colour, except Pf8, Pf18 and Pf14, Pf16 showed fluorescent blue and greenish yellow colour, respectively, under UV-trans-illuminator. Two isolates from Punjab (Pf4 and Pf7), one isolate from Uttar Pradesh (Pf12) and 2 isolates from Bihar (Pf21 and Pf22) not showed any fluorescent. All bacterial isolates produced catalase enzyme, which used by all aerobic microorganisms. All the isolates were motile, except isolates Pf7, Pf12, Pf20 and Pf21. The morphological, biochemical and physiological characters of most of the isolates were typical properties of Pseudomonas spp (Stanier et al. 1966). The isolates were identified as Pseudomonas spp. on basis of biochemical and morphological characters.

\section{Screening for antagonistic activity}

All bacterial isolates were screened for antagonistic activity against major soil and tuber-borne fungal pathogens infecting potato in dual culture on PDA plates. Among 22 isolates, 2 isolates i.e. Pf10 and Pf14 showed different degree of mycelial growth inhibition of all the tested fungal pathogens (Fig. 1a, b). Isolate Pf14 (isolated from maize rhizosphere soil of Uttar Pradesh) displayed a strong growth inhibitory activity ranged from 62.2 to $59.3 \%$ against different fungal pathogens (Table 2) and selected for further study.

\section{Antagonistic activity due to antifungal volatile compounds (VOCs)}

The mouth-to-mouth sealed plate assay allows no physical contact between fungal pathogens and bacterial colonies. Therefore, observed mycelial growth inhibition could be a result of VOCs production. Isolate Pf14 produced VOCs, as evident from the mycelial growth inhibition of all the fungal pathogens in sealed plates.

Table 1 Morphological characteristics of bacterial isolates collected from various rhizosphere soils of different geographical locations

\begin{tabular}{|c|c|c|c|c|c|c|c|c|}
\hline Bacterial isolate & Geographical location & Crop & Fluorescence colour & Shape & $\begin{array}{l}\text { Gram } \\
\text { staining }\end{array}$ & $\begin{array}{l}\text { Catalase } \\
\text { production }\end{array}$ & Motility & Sporulation \\
\hline$P f 1$ & Punjab & Rice & Fluorescent green & Short rod & - & + & + & - \\
\hline $\mathrm{Pf} 2$ & Punjab & Rice & Fluorescent green & Short rod & - & + & + & - \\
\hline Pf3 & Punjab & Rice & Fluorescent green & Short rod & - & + & + & - \\
\hline Pf4 & Punjab & Maize & $\mathrm{NI}$ & Long rod & + & + & + & + \\
\hline Pf5 & Punjab & Maize & Fluorescent green & Short rod & - & + & + & - \\
\hline Pf6 & Punjab & Maize & Fluorescent green & Short rod & - & + & + & - \\
\hline Pf7 & Punjab & Potato & $\mathrm{NI}$ & Long rod & + & + & - & + \\
\hline Pf8 & Punjab & Potato & Fluorescent blue & Short rod & - & + & + & - \\
\hline Pfg & Punjab & Potato & Fluorescent green & Short rod & - & + & + & - \\
\hline Pf10 & Punjab & Potato & Fluorescent green & Short rod & - & + & + & - \\
\hline Pf11 & Uttar Pradesh & Rice & Fluorescent green & Short rod & - & + & + & - \\
\hline Pf12 & Uttar Pradesh & Rice & $\mathrm{NI}$ & Long rod & + & + & - & + \\
\hline Pf13 & Uttar Pradesh & Rice & Fluorescent green & Short rod & - & + & + & - \\
\hline Pf14 & Uttar Pradesh & Maize & Greenish yellow & Short rod & - & + & + & - \\
\hline Pf15 & Uttar Pradesh & Maize & Fluorescent green & Short rod & - & + & + & - \\
\hline Pf16 & Uttar Pradesh & Maize & Greenish yellow & Short rod & - & + & + & - \\
\hline Pf17 & Uttar Pradesh & Potato & Fluorescent green & Short rod & - & + & + & - \\
\hline Pf18 & Uttar Pradesh & Potato & Fluorescent blue & Short rod & - & + & + & - \\
\hline Pf19 & Uttar Pradesh & Potato & Fluorescent green & Short rod & - & + & + & - \\
\hline Pf20 & Uttar Pradesh & Potato & Fluorescent green & Short rod & - & + & - & - \\
\hline Pf21 & Bihar & Potato & $\mathrm{NI}$ & Long rod & + & + & - & + \\
\hline Pf22 & Bihar & Potato & $\mathrm{NI}$ & Long rod & + & + & + & + \\
\hline
\end{tabular}



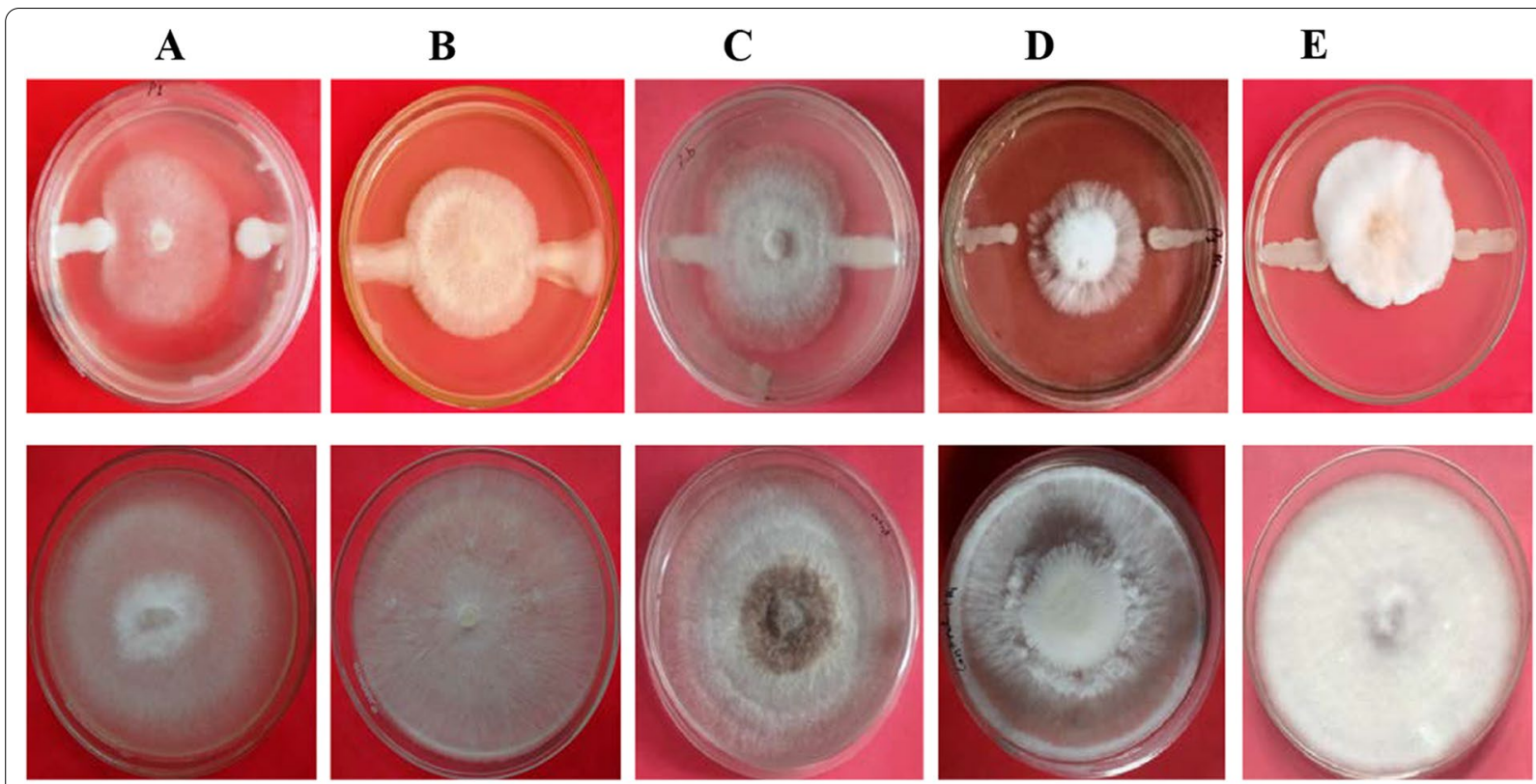

(A)

A
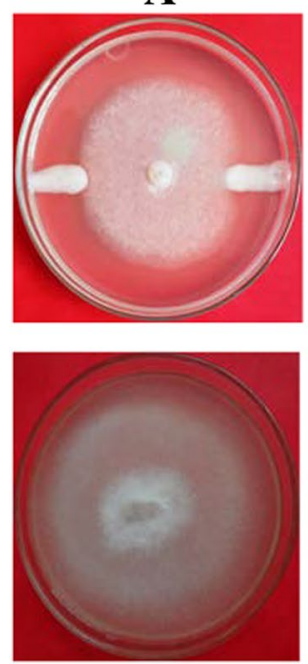

B
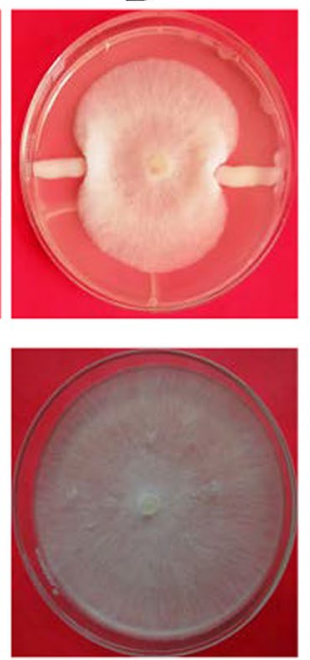

C
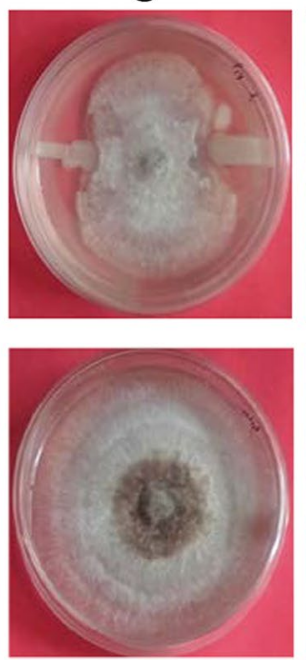

D

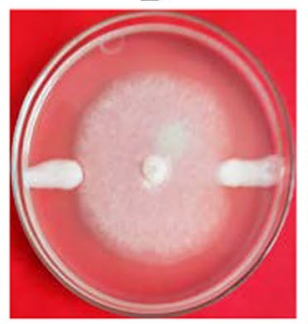

$\mathbf{E}$

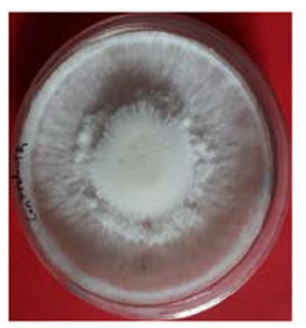

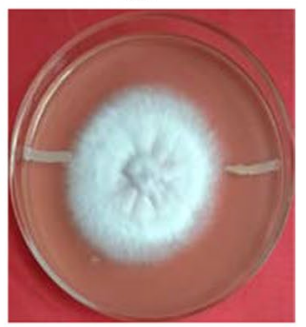

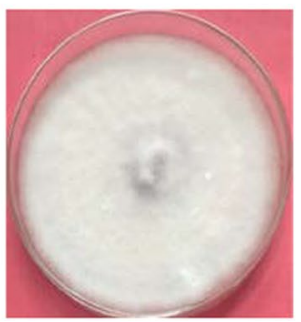

(B)

Fig. 1 a In vitro confrontation of major potato fungal pathogens with Pseudomonas spp. Pf14 strain (up) and control (down) of (A) S. sclerotiorum, (B) R. solani AG1-IA, (C) R. solani AG3, (D) S. rolfsii and (E) Fusarium spp. on potato dextrose agar (PDA). $\mathbf{b}$ In vitro confrontation of major potato fungal pathogens with Pseudomonas spp. Pf10 strain (up) and control (down) of (A) S. sclerotiorum, (B) R. solani AG1-IA, (C) R. solani AG3, (D) S. rolfsii and (E) Fusarium spp. on PDA

Isolate Pf14 significantly inhibited the radial mycelial growth ranged from $>80 \%$ to $>50 \%$ of different fungal pathogens as compared to control (Table 2, Fig. 2). Additionally, aerial mycelial growth was also distorted due to the action of VOCs from bacterial isolates.

\section{Antagonistic activity of cell-free culture filtrate}

The culture filtrate of isolate Pf14 showed significant antagonistic activity against all the tested fungal pathogens. Maximum mycelial growth inhibition (67.1\%; R. solani AG3, 42.6\%; R. solani AG1-IA, 55.6\%; S. sclerotiorum, 62.6\%; S. rolfsii and 68.9\%; Fusarium spp.) was recorded by CFCF (Cell-Free Culture Filtrate) from 48 h-old culture, followed by $(46.7 \%$; $R$. solani AG3, 34.4\%; R. solani AG1-IA, 34.1\%; S. sclerotiorum, 42.9\%; S. rolfsii and 44.1\%; Fusarium spp.) with CFCF from 24 h-old culture (Fig. 3a, b). 
Table 2 Antagonistic activities of different bacterial isolates in dual culture and effect of volatile compounds on various potato pathogens

\begin{tabular}{|c|c|c|c|c|c|c|c|c|c|c|}
\hline \multirow[t]{3}{*}{ Strain } & \multicolumn{10}{|c|}{ Percent (\%) growth inhibition } \\
\hline & \multicolumn{2}{|c|}{ R. solani (AG1-IA) } & \multicolumn{2}{|l|}{ R. solani (AG3) } & \multicolumn{2}{|c|}{ Sclerotinia sclerotiorum } & \multicolumn{2}{|l|}{ Fusarium spp. } & \multicolumn{2}{|c|}{ Sclerotium rolfssi } \\
\hline & Dual culture & Volatile & Dual culture & Volatile & Dual culture & Volatile & Dual culture & Volatile & Dual culture & Volatile \\
\hline Pf1 & $20.4(26.9)$ & $11.1(19.5)$ & $48.2(43.9)$ & $27.8(31.8)$ & $28.9(32.5)$ & $20.0(26.6)$ & 40.0 (39.2) & $3.7(11.1)$ & $25.9(30.6)$ & $40.0(39.2)$ \\
\hline $\mathrm{Pf} 2$ & $40.8(39.7)$ & $17.8(24.9)$ & $48.9(44.4)$ & $32.6(34.8)$ & $43.3(41.2)$ & $0.0(0.0)$ & $39.6(39.1)$ & $11.1(19.5)$ & 38.9 (38.6) & $45.6(42.5)$ \\
\hline Pf3 & $38.9(38.6)$ & $17.8(24.9)$ & $32.2(34.6)$ & $42.2(40.5)$ & $9.6(18.1)$ & $76.7(61.1)$ & $32.2(34.6)$ & $1.1(6.1)$ & $18.5(25.5)$ & $4.8(12.7)$ \\
\hline $\mathrm{Pf} 4$ & $27.8(31.8)$ & $11.1(19.2)$ & $38.5(38.4)$ & $80.0(63.4)$ & $42.2(40.5)$ & $0.0(0.0)$ & $33.3(35.3)$ & $31.1(33.9)$ & $20.4(26.8)$ & $72.2(58.2)$ \\
\hline Pf5 & $27.8(31.8)$ & $42.6(40.8)$ & $32.9(35.1)$ & $84.7(66.5)$ & $20.0(26.6)$ & $76.7(61.1)$ & $41.1(39.9)$ & $41.8(40.1)$ & $27.8(31.8)$ & $63.3(52.7)$ \\
\hline Pf6 & 11.1 (19.5) & $0.7(4.9)$ & $4.4(12.2)$ & $33.3(35.3)$ & $20.4(26.9)$ & $10.0(18.4)$ & $32.2(34.6)$ & $1.1(6.1)$ & $27.8(31.8)$ & $32.2(34.6)$ \\
\hline Pf7 & $46.3(42.9)$ & $2.2(8.6)$ & $57.8(49.5)$ & $83.3(65.9)$ & $51.5(45.9)$ & 78.9 (62.6) & $40.0(39.2)$ & 11.1 (19.5) & $35.2(36.4)$ & $28.9(32.5)$ \\
\hline Pf8 & 38.9 (38.6) & $16.7(24.1)$ & $44.4(41.8)$ & $27.8(31.8)$ & 18.9 (25.8) & $65.6(54.1)$ & 39.3 (38.8) & $22.2(28.1)$ & $16.7(24.1)$ & $50.4(45.2)$ \\
\hline Pfg & $27.8(31.8)$ & $6.3(14.3)$ & $49.6(44.8)$ & $50.8(45.4)$ & $10.0(18.4)$ & $32.9(35.1)$ & $33.3(35.3)$ & $0.4(3.5)$ & $5.6(13.6)$ & $55.6(48.2)$ \\
\hline Pf10 & 48.5 (43.9) & $65.6(54.1)$ & $61.1(51.4)$ & $85.6(67.7)$ & $51.9(46.1)$ & 86.7 (68.6) & $50.0(45.0)$ & $57.4(49.3)$ & $44.4(41.8)$ & $76.3(60.9)$ \\
\hline Pf11 & 38.9 (38.6) & $13.3(21.4)$ & $33.3(35.3)$ & $39.3(38.8)$ & 18.5 (25.5) & 79.6 (63.2) & 33.7 (35.5) & $50.0(45.0)$ & $42.6(40.7)$ & $66.7(54.7)$ \\
\hline Pf12 & $27.8(31.8)$ & $5.6(13.6)$ & $38.5(38.2)$ & $39.3(38.8)$ & $21.1(27.4)$ & 70.0 (56.8) & $43.3(41.2)$ & 11.5 (19.8) & 38.9 (38.6) & $11.1(19.5)$ \\
\hline Pf13 & $44.4(41.8)$ & $0.4(3.5)$ & $47.8(43.7)$ & $83.3(65.9)$ & $31.1(33.9)$ & $21.8(27.9)$ & $32.2(34.6)$ & $10.0(18.4)$ & $27.8(31.8)$ & $40.0(39.2)$ \\
\hline Pf14 & $59.3(50.4)$ & 76.7 (61.1) & $61.1(51.4)$ & $84.8(67.1)$ & $54.7(47.3)$ & 88.2 (69.9) & $62.2(52.1)$ & $52.9(46.7)$ & $55.6(48.2)$ & $80.0(63.4)$ \\
\hline Pf15 & $44.4(41.8)$ & $48.5(44.2)$ & $27.8(31.8)$ & $40.4(39.4)$ & $16.7(24.1)$ & $1.1(6.1)$ & $40.0(39.2)$ & $28.5(32.3)$ & $16.7(24.1)$ & $72.2(58.2)$ \\
\hline Pf16 & $37.1(37.5)$ & $15.6(23.2)$ & $54.4(47.5)$ & $84.4(66.8)$ & 48.9 (44.4) & 79.6 (63.2) & $44.4(41.8)$ & $21.1(27.4)$ & 29.6 (32.9) & $39.3(38.8)$ \\
\hline Pf17 & 38.9 (38.6) & $23.3(28.9)$ & $32.2(34.6)$ & $50.7(45.4)$ & $27.4(31.3)$ & $76.6(61.1)$ & 36.7 (37.3) & $10.0(18.4)$ & $37.4(37.5)$ & $26.7(31.1)$ \\
\hline Pf18 & $22.2(28.1)$ & 38.9 (38.6) & $5.6(13.6)$ & 75.9 (60.6) & $18.2(25.2)$ & $4.4(12.2)$ & $42.2(40.5)$ & $10.4(18.8)$ & $31.5(34.1)$ & $62.2(52.1)$ \\
\hline Pf19 & $37.4(37.5)$ & $0.4(3.5)$ & $44.4(41.8)$ & $45.6(42.5)$ & $8.9(17.3)$ & $51.1(45.6)$ & $40.0(39.2)$ & $1.1(6.1)$ & $33.3(35.3)$ & $48.9(44.4)$ \\
\hline Pf20 & $31.5(34.1)$ & $1.1(6.1)$ & $48.9(44.4)$ & $80.4(63.7)$ & $20.0(26.6)$ & $83.7(66.2)$ & $40.0(39.2)$ & $1.5(6.9)$ & 27.8 (31.8) & $43.3(41.2)$ \\
\hline Pf21 & $44.4(41.8)$ & $26.7(31.1)$ & $0.8(4.9)$ & $82.2(65.1)$ & $46.7(43.1)$ & 38.9 (38.6) & $35.9(36.8)$ & $17.4(24.7)$ & $31.5(34.1)$ & $8.9(17.3)$ \\
\hline Pf22 & $33.3(35.2)$ & $2.2(8.6)$ & $43.3(41.2)$ & $39.3(38.8)$ & $19.6(26.3)$ & $9.6(18.1)$ & $30.0(33.2)$ & $17.4(24.7)$ & $27.8(31.8)$ & $10.8(19.2)$ \\
\hline
\end{tabular}

\section{Quantitative evaluation of antagonism of the selected isolate in different media}

To evaluate the antagonistic activity of the prominent isolate Pf14 in different media a broth-based dual coculture assay was used. Isolate Pf14 showed a significant reduction in biomass of all the tested fungi in dual culture using 6 different broth media. Maximum biomass reduction was observed in King's B broth (KBB), followed by nutrient broth (NA) and potato dextrose broth (PDB). Reduction in biomass varied from $>80.0 \%$ (KBB) to $>45.0 \%$ (TYEB) for all the fungal pathogens compared to the respective fungus non-inoculated control (Fig. 4).

\section{Phosphate solubilisation activity}

Phosphate solubilisation potential of bacterial isolates was anticipated by recording the clear halo zone around the bacterial colonies on PVK agar medium. Phosphate solubilisation index (PSI) and solubilisation efficiency (SE) of all isolates were calculated. PSI and SE for all the bacterial isolates varied from 5.65 to 1.88 and $82.29 \%$ to $46.67 \%$, respectively. Maximum PSI was recorded with isolate Pf14 (5.65), followed by Pf10 (4.50) and Pf11 (4.50). Similarly, highest SE was observed by Pf14 (82.29\%), followed by Pf10 (77.78\%) and Pf11 (77.78\%) (Table 3; Fig. 5).

\section{Evaluation of antagonistic and growth enhancement potentials of Pf10 and Pf 14 under field conditions Growth enhancement activities}

Emergence percentage ranged (84.63-97.17\%), including untreated control. The highest emergence percent (97.17\%) was recorded by spore suspension of Pf10, followed by Pf14 cell suspension (96.33\%). These treatments were significantly differing from each other. The lowest emergence percentage $(84.63 \%)$ was recorded in untreated control (Table 4). The highest number of stem per plant (6.5) was recorded in spore suspensions of both Pf10 and Pf14 against untreated control (4.1) (Fig. 6). The highest number of leaves per plant (81.3) was observed in Pf14 talc based formulation, followed by Pf14 talc spore suspension (79.6) as against untreated control (38.9). The highest plant 

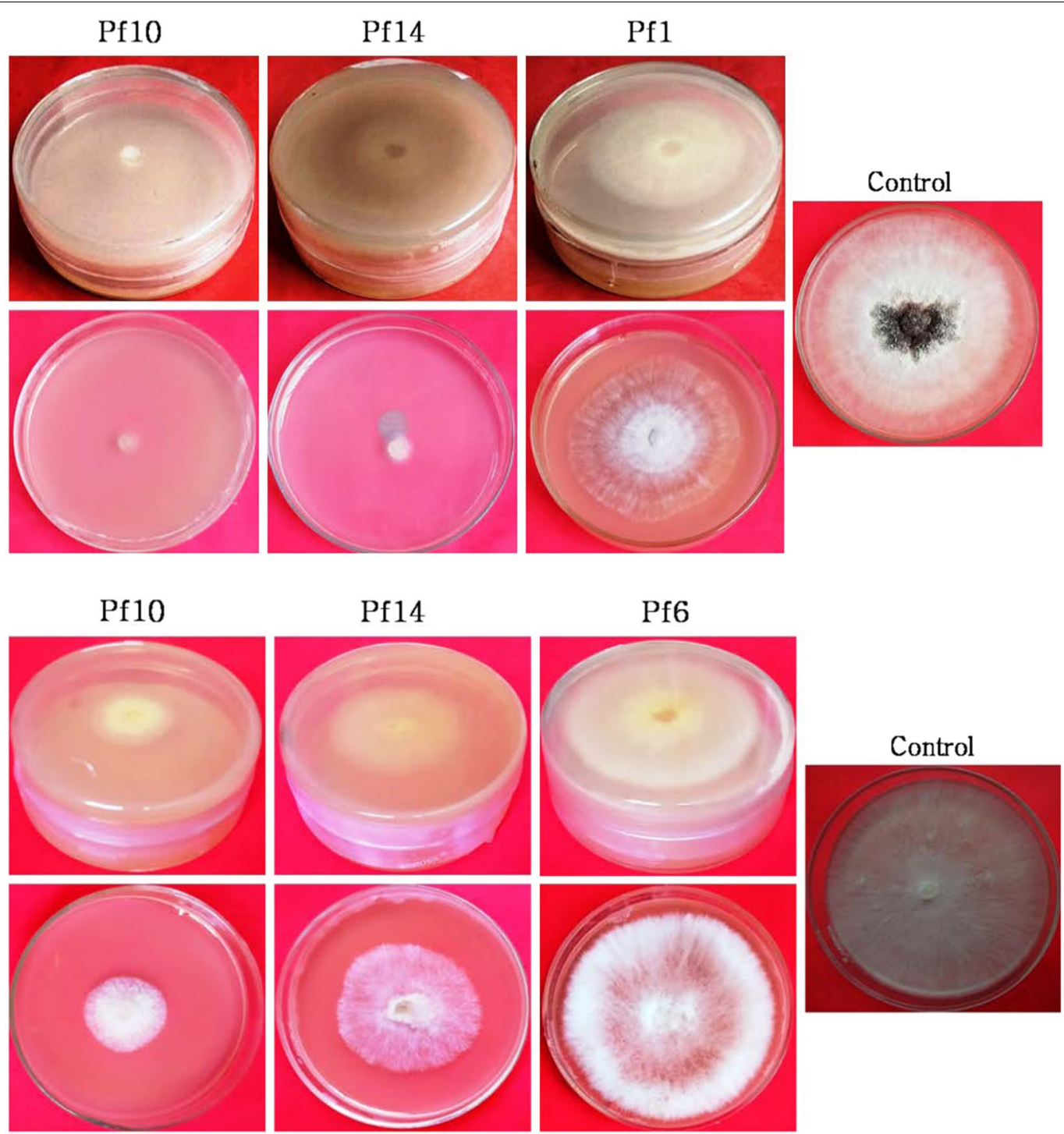

(A)
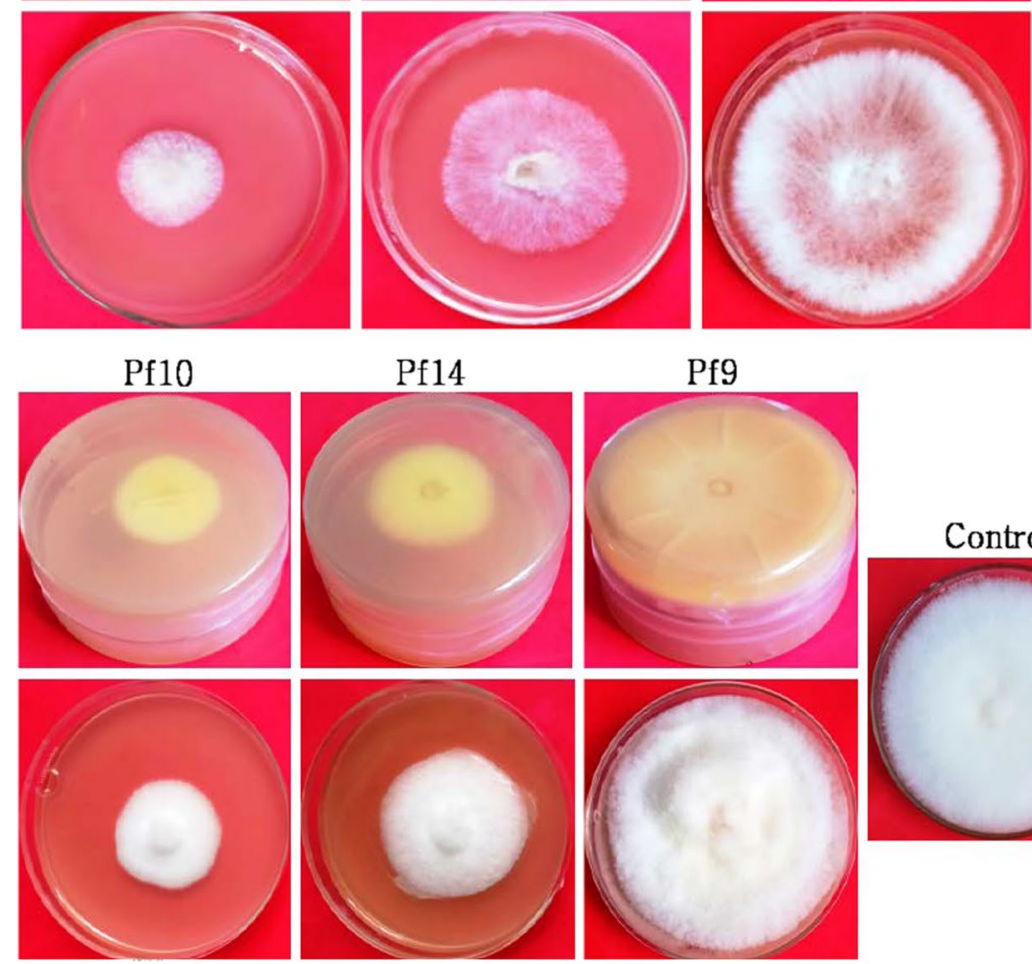

(B)
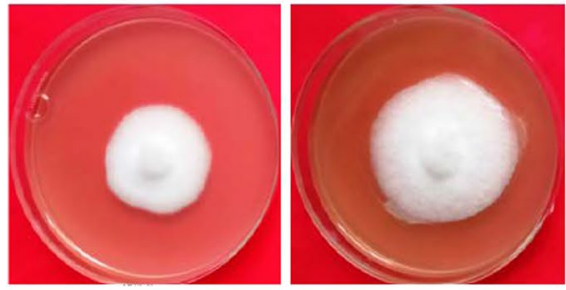

(C)

Fig. 2 Effect of volatile compounds from different Pseudomonas isolates against a R. solani AG3 b R. solani AG1-IA c Fusarium spp. on PDA 


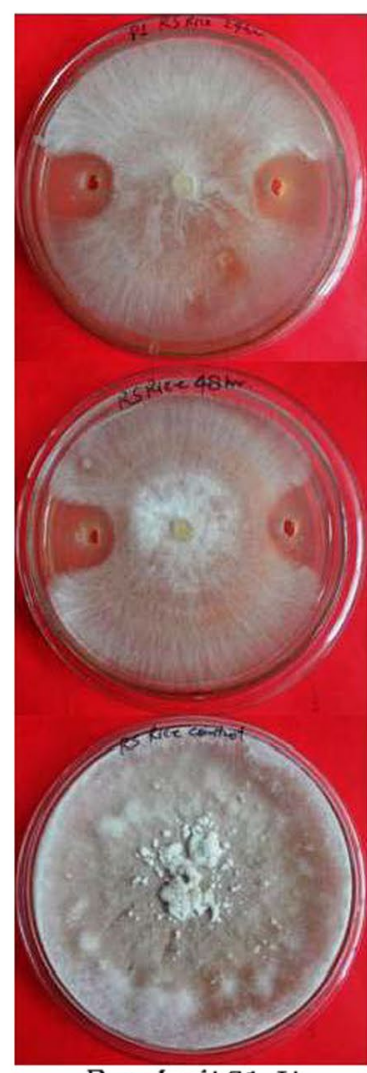

R. solaniAG1-IA

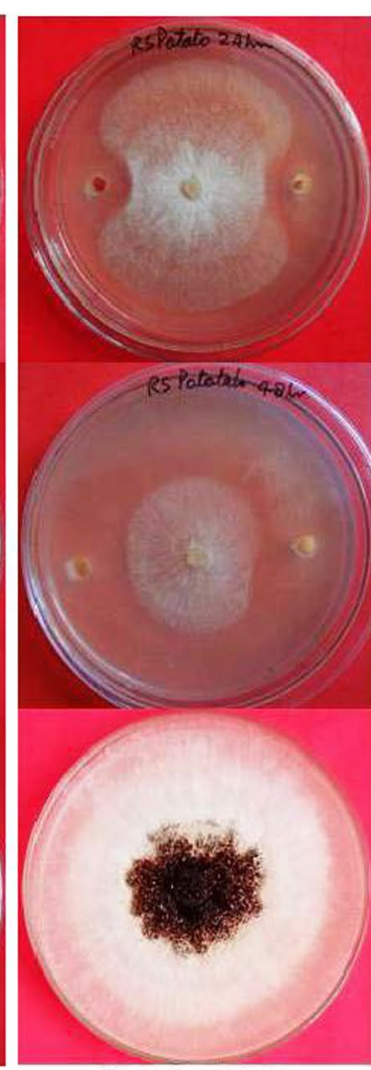

R. solaniAG3

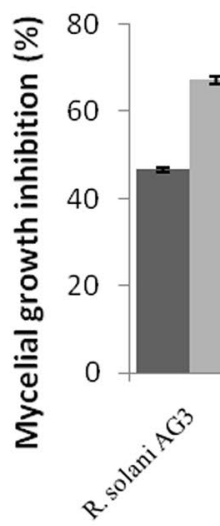

- $24 \mathrm{~h}$

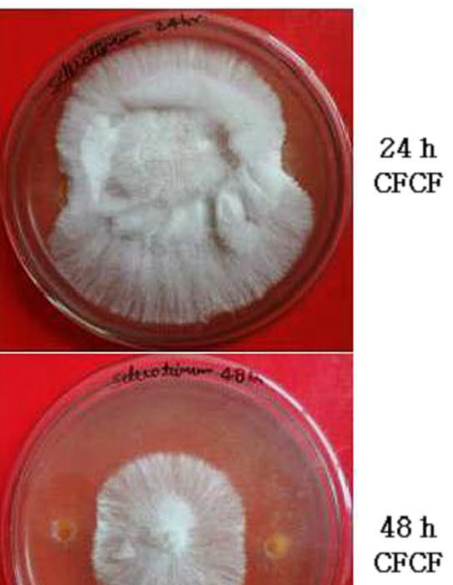

CFCF

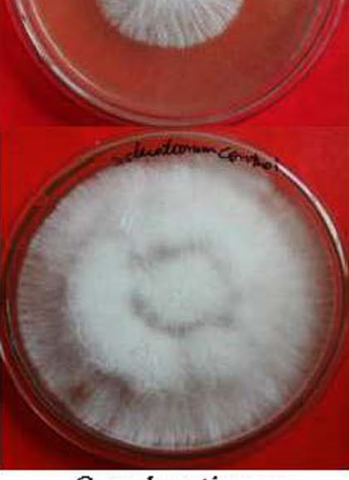

S. sclerotiorum

(A)

Control

(B)

Fig. 3 a Mycelial growth inhibition of different potato fungal pathogens by cell-free culture filtrates from isolate Pf14 in dual culture on PDA. b Graphical representation of mycelial growth inhibition of potato fungal pathogens by cell-free culture filtrates (CFCF) from isolate Pf14 in dual culture on PDA. The error bars represent standard deviation of the mean value. The $p$ value for $24 \mathrm{~h}$ is 0.00016 and for $48 \mathrm{~h}$ is 0.00001

height $(63.4 \mathrm{~cm})$ was measured in Pf14 talc based formulation, followed by Pf14 spore suspension $(60.3 \mathrm{~cm})$ against untreated control $(40.8 \mathrm{~cm})$. The maximum root length $(21.4 \mathrm{~cm})$ was measured in Pf14 talc based formulation, followed by Pf10 spore suspension
$(19.8 \mathrm{~cm})$ as against untreated control $(13.5 \mathrm{~cm})$. Similarly maximum root volume $(36.0 \mathrm{cc})$ was measured in P14 talc formulation, followed by P14 spore suspension $(34.0 \mathrm{cc})$ (Fig. 7). 


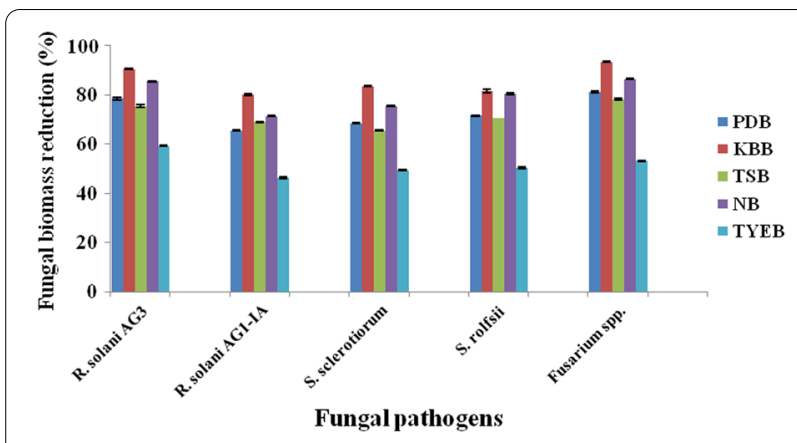

Fig. 4 Percent biomass reduction of different fungal pathogens in broth based dual culture with isolate Pf14 in different media. The error bars represent SD of the mean value. The $p$ value is 0.00001

Table 3 Phosphate solubilisation efficacies of different bacterial isolates

\begin{tabular}{llllll}
\hline Strain & $\mathbf{d}^{*}(\mathbf{c m})$ & $\mathbf{D}^{*}(\mathbf{c m})$ & $\begin{array}{l}\mathbf{S R}^{*} \\
(\mathbf{D}-\mathbf{d})\end{array}$ & $\begin{array}{l}\mathbf{S E}^{*} \\
(\mathbf{D}-\mathbf{d}) / \mathbf{D} \times \mathbf{1 0 0}\end{array}$ & $\begin{array}{l}\mathbf{S I}^{*} \\
(\mathbf{D} / \mathbf{d})\end{array}$ \\
\hline Pf1 & $0.90 \pm 0.10$ & $2.90 \pm 0.10$ & 2.00 & 68.97 & 3.22 \\
Pf2 & $1.03 \pm 0.06$ & $2.33 \pm 0.06$ & 1.30 & 55.71 & 2.26 \\
Pf3 & $0.57 \pm 0.06$ & $2.50 \pm 0.10$ & 1.93 & 77.33 & 4.41 \\
Pf4 & $0.53 \pm 0.06$ & $2.13 \pm 0.15$ & 1.60 & 75.00 & 4.00 \\
Pf5 & $0.67 \pm 0.06$ & $1.97 \pm 0.06$ & 1.30 & 66.10 & 2.95 \\
Pf6 & $0.67 \pm 0.12$ & $2.30 \pm 0.10$ & 1.63 & 71.01 & 3.45 \\
Pf7 & $0.60 \pm 0.10$ & $2.50 \pm 0.10$ & 1.90 & 76.00 & 4.17 \\
Pf8 & $0.67 \pm 0.12$ & $2.20 \pm 0.10$ & 1.53 & 69.70 & 3.30 \\
Pf9 & $0.50 \pm 0.10$ & $2.00 \pm 0.10$ & 1.44 & 72.17 & 3.59 \\
Pf10 & $0.53 \pm 0.06$ & $2.40 \pm 0.10$ & 1.87 & 77.78 & 4.50 \\
Pf11 & $0.67 \pm 0.06$ & $3.00 \pm 0.10$ & 2.33 & 77.78 & 4.50 \\
Pf12 & $0.53 \pm 0.06$ & $1.00 \pm 0.10$ & 0.47 & 46.67 & 1.88 \\
Pf13 & $0.53 \pm 0.06$ & $2.10 \pm 0.10$ & 1.57 & 74.60 & 3.94 \\
Pf14 & $0.57 \pm 0.06$ & $3.20 \pm 0.10$ & 2.63 & 82.29 & 5.65 \\
Pf15 & $0.57 \pm 0.06$ & $2.30 \pm 0.10$ & 1.73 & 75.36 & 4.06 \\
Pf16 & $0.53 \pm 0.06$ & $2.30 \pm 0.10$ & 1.77 & 76.81 & 4.31 \\
Pf17 & $0.50 \pm 0.06$ & $1.97 \pm 0.06$ & 1.43 & 72.88 & 3.69 \\
Pf18 & $0.83 \pm 0.06$ & $2.40 \pm 0.10$ & 1.57 & 65.28 & 2.88 \\
Pf19 & $0.67 \pm 0.06$ & $2.40 \pm 0.10$ & 1.73 & 72.22 & 3.60 \\
Pf20 & $0.80 \pm 0.12$ & $1.90 \pm 0.10$ & 1.17 & 61.40 & 2.59 \\
Pf21 & $0.83 \pm 0.06$ & $2.80 \pm 0.10$ & 1.97 & 70.24 & 3.36 \\
Pf22 & $0.53 \pm 0.06$ & $1.50 \pm 0.10$ & 0.97 & 64.44 & 2.81 \\
\hline
\end{tabular}

$\mathrm{d}^{*}$ : colony diameter; $\mathrm{D}^{*}$ : Total diameter (colony + halo zone); $\mathrm{SR}^{*}$ : Solubilization rate; $\mathrm{SE}^{*}$ :Solubilization Efficiency; $\mathrm{Sl}$ : Solubilization Index

\section{Effect on disease incidence}

The stem canker incidence ranged (20-60\%), including untreated control. The lowest stem canker incidence (20.00\%) was observed in Pf14 talc based formulation, followed by Pf14 cell suspension (30.00\%) and Pf10 talc based formulation (Table 4). These treatments were statistically significant. The lowest black scurf disease incidence $(38.00 \%)$ and disease severity $(15.50 \%)$ were recorded in Pf14 talc based formulation, followed by Pf10 talc based formulation (62.67\%, DI 29.83\% DS). The highest percentage of disease control was recorded in Pf14 talc based formulation, followed by Pf14 spore suspension. The highest tuber yield (21.90 t/ha) was recorded in Pf14 talc based formulation, followed by Pf10 talc based formulation $(20.85 \mathrm{t} / \mathrm{ha})$ as against control (18.98 t/ha). Although these treatment were statistically at par each other and significantly differ from control treatment. The yield increased with 4.32 and $15.38 \%$ was recorded in spore suspension of Pf10 and Pf14 talc based formulation, respectively treated infested seed tuber in comparison to untreated control.

\section{Discussion}

The control and management of potato diseases, especially soil and seed-borne, is often based on a tremendous use of synthetic fungicides, causing negative impact on human health and environment. The search for an eco-friendly disease management strategy has led to study non-pathogenic microorganisms having antagonistic potentials (Caulier et al. 2018). Till date, several antagonistic agents have been identified from soils, of which Pseudomonas spp. are important as they are vigorously colonizes the various crops and show a broad spectrum of antagonistic activities against soil and seed-borne pathogens (Wang et al. 2018). For example, P. aeruginosa BA5 showed a better antagonistic potential against Fusarium oxysporum f. sp. cucumerinum with phosphate solubilisation capability (Islam et al. 2018). P. fluorescens, with its plant-growth promotion and root colonization potentials, reduced the disease symptoms produced by $R$. solani on potato (Bautista et al. 2007).

The investigation of antagonistic characteristics of bio-agents is often important for understanding biocontrol mechanisms to get better control efficacy of the antagonists. In this study, 22 native bacterial strains from rhizospheric soil of rice, maize and potato crops were isolated and screened the potential bacterial strains for their in vitro antagonistic and phosphate solubilization capabilities against major soil and tuber-borne pathogens of potato. Identified potential bacterial isolates were developed in talc and spore suspension formulations and evaluated for growth enhancement parameters and bioefficacy against $R$. solani causing black scurf of potato under field condition. According to morphological and phenotypic properties, most of the isolates were identified as Pseudomonas spp. In dual culture assay, one isolates namely, Pf14 was the most promising antagonist and inhibit the mycelium growth ranged from 62.2 to $59.3 \%$ of the tested pathogens. This result indicated that Pf14 had potential to inhibit the mycelial growth of soil and tuber borne pathogens of potato. Dual culture assay is 

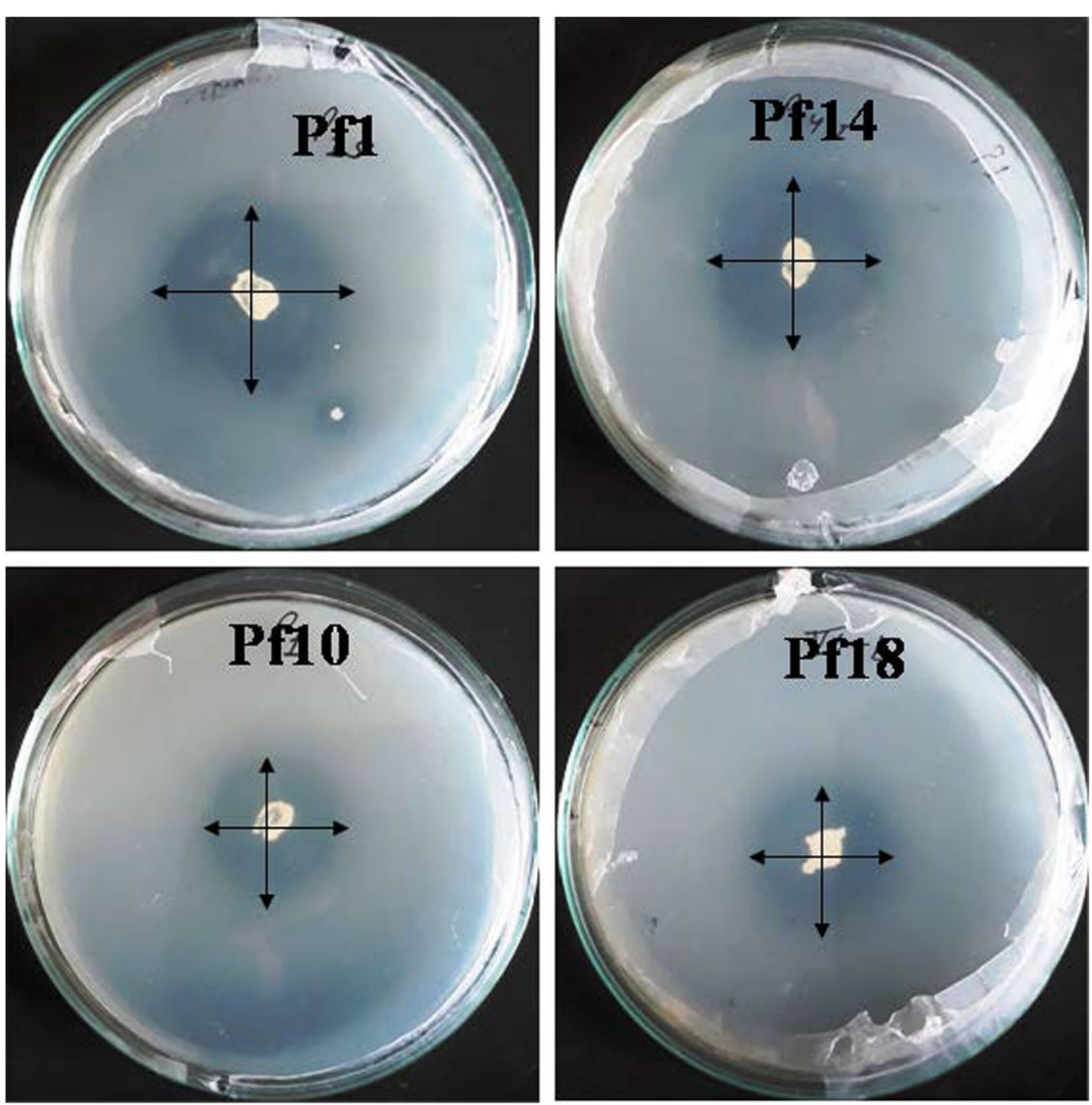

Fig. 5 In vitro assay for phosphate solubilization by different strains of Pseudomonas spp

Table 4 Antagonistic and growth enhancement potentials of Pf10 and Pf14 against Rhizoctonia diseases of potato under field conditions

\begin{tabular}{|c|c|c|c|c|c|c|c|c|c|}
\hline \multirow[t]{3}{*}{ Treatments } & \multirow[t]{3}{*}{ Emergence (\%) } & \multirow{3}{*}{$\begin{array}{l}\text { Stem canker } \\
\text { DI (\%) }\end{array}$} & \multirow{2}{*}{\multicolumn{2}{|c|}{ Black scurf }} & \multicolumn{3}{|c|}{ Disease controlled (\%) } & \multirow[t]{3}{*}{ Yield (t/ha) } & \multirow{3}{*}{$\begin{array}{l}\text { Yield } \\
\text { over } \\
\text { control }\end{array}$} \\
\hline & & & & & \multirow{2}{*}{$\begin{array}{l}\text { Stem canker } \\
\text { DI (\%) }\end{array}$} & \multicolumn{2}{|c|}{ Black scurf } & & \\
\hline & & & DI (\%) & DS (\%) & & DI (\%) & DS (\%) & & \\
\hline Pf10 Cell suspension & 97.17 & 50.00 & 79.33 & 38.67 & 16.67 & 11.19 & 19.16 & 19.80 & 4.32 \\
\hline Pf10 Talc formulation & 95.75 & 30.00 & 62.67 & 29.83 & 50.00 & 14.67 & 25.13 & 20.85 & 9.85 \\
\hline Pf14 Cell suspension & 96.33 & 30.00 & 76.23 & 35.81 & 50.00 & 29.85 & 37.63 & 20.79 & 9.54 \\
\hline Pf14 Talc formulation & 95.17 & 20.00 & 38.00 & 15.50 & 66.67 & 57.46 & 67.59 & 21.90 & 15.38 \\
\hline Control & 84.63 & 60.00 & 89.33 & 47.83 & - & - & - & 18.98 & - \\
\hline CD (0.05) & 0.68 & 4.28 & 10.08 & 3.94 & - & - & - & 1.77 & - \\
\hline $\mathrm{SE}(\mathrm{m})$ & 0.21 & 1.30 & 3.04 & 1.19 & - & - & - & 0.53 & - \\
\hline
\end{tabular}




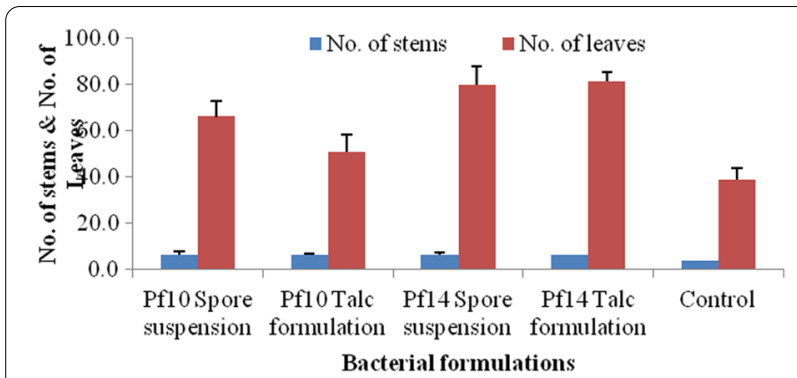

Fig. 6 Effect of bacterial formulations on no. of stems and no. of leaves of potato plants. The error bars represent SD of the mean value. The $p$ value for no. of stem is 0.00002 and for no. of leaves is 0.00001

one of the key tests used for in vitro preliminary screening of antagonistic agents (Islam et al. 2018). Antagonistic effects of a bacterial strain are often confirmed by the formation of inhibition zones between the bacterial colonies and the fungal colonies (Ji et al. 2014) or by calculating the radial mycelial growth inhibition (\%) towards the bacterial colonies against control (Lee et al. 2017). Previous studies suggested that, Pseudomonas species deploy antagonistic activities against plant pathogens by synthesizing siderophores, secreting lytic enzymes, competing for nutrients and niches, and inducing systemic resistance (Kang et al. 2015). The bacterial pigment pyocyanin produced by Pseudomonas aeruginosa, reduced the growth of the fungus Magnaporthe grisea and the bacterium Xanthomonas oryzae in vitro study (DeBritto et al.2020).

Antifungal volatile compounds (VOCs) like hydrogen cyanide $(\mathrm{HCN})$ and ammonia $\left(\mathrm{NH}_{3}\right)$ are produced by many PGPRs and reported to play an important role in antagonism (Islam et al. 2018). In the present study, Pseudomonas spp. produced VOCs, as evident from the mycelial growth inhibition of all tested fungi in sealed plates. Recently, Islam et al. (2018) demonstrated the role of VOCs produced by Pseudomonas spp. in antagonistic activities. In some studies, the inhibitory effect of VOCs received less importance than the inhibitory effect of diffusible metabolites (Tripathi and Johri 2002). In contrast, present study demonstrated that the VOCs produced by Pseudomonas spp. had a predominant inhibitory role of the antagonism against $R$. solani, S. sclerotiorum, S. rolfsii and Fusarium spp. It may be reason that VOCs have different antagonistic compounds.

Broth-based in vitro dual culturing may be a better method to evaluate the antagonistic potential of the bioagents, as the liquid broth media provide a favourable environment to allow the antagonisms from all possible interacting sites (Trivedi et al. 2008). Isolate Pf14 significantly reduced the biomass of all the tested fungi in different broth medium, however, fungal biomass reduction varied among growth media. Because, these media have different composition with regards to their nutritional status. According to Trivedi et al. (2008) variations in fungal biomass reduction in different growth media were indicative of the effect of nutritional factors. Antagonistic activity of isolate Pf14 was also determined in terms of 'time course' of inhibition in fungal growth using culture filtrates (CFCFs) of different time intervals. Maximum mycelial growth inhibition was observed by CFCF from 48-h (i.e. stationary phase) incubated broth culture. It has been reported that antagonism is generally mediated by the production of secondary metabolites, most of them are produced in the stationary growth phase (Vining, 1990).

Phosphorus is an important mineral nutrients required for the growth and yield of agriculturally important crops. It is essential for root development of potato crop. Phosphate solubilising bacteria solubilise the complex phosphate compounds present in soil into the simpler readily absorbable form (Tomer et al. 2017). In this study, isolate Pf14 showed highest phosphate

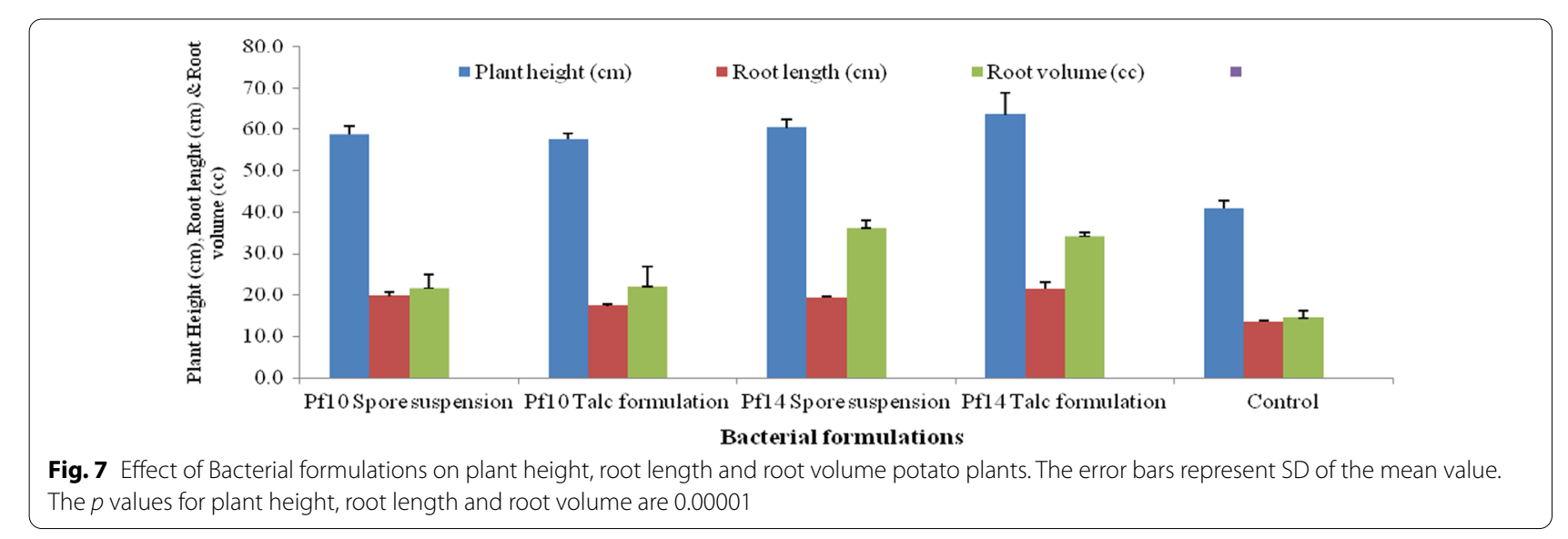


solubilisation efficiency on PVK media. El-Komy (2005) concluded that $P$. fluorescens and B. megaterium strains were able to solubilise phosphate effectively and recorded a higher solubilization efficiency on PVK plates. Similarly, phosphate solubilising Pseudomonas species were also reported from subtropical regions of Western Indian Himalaya in India (Tomer et al. 2017). Recently, phosphate solubilisation in P. aeruginosa BA5 has been reported by Islam et al. (2018).

Pseudomonas species are well-known to inhibit the phytopathogen population via different modes of action, but their in-vitro activities are not easily transferable to in-vivo assays, especially under field conditions (Glare et al. 2012). Under in-vivo conditions, the major limitations affecting the efficacy of a bio-agent includes biotic (host species, other bioagents, pathogen), abiotic (temperature, wetness, relative humidity) factors (Sundin et al. 2009) and modes of application. The low performance of a bio-agent is usually due to difficulties in colonization and survival in the environment in which it applies, because fitness of bio-agents is limited under field conditions. In this study, infested seed tubers treated with talc based formulation of Pf14 showed better growth enhancement potentials and decrease black scurf severity up to $67.59 \%$ under field conditions. This treatment also recorded highest tuber yield (21.90 t/ha) with an increase of $15.38 \%$ in comparison to untreated control. Few reports showed the effectiveness of fluorescent Pseudomonas spp. against major potato diseases under field applications (Mrabet et al. 2015). In a pilot field trial Caulier et al (2018) found Bacillus spp. and Pseudomonas spp. effective against late blight of potato and decrease disease severity throughout the crop season. Recently, in a field experiment, Lal et al. (2021) found P. fluorescens effective against late blight which showed better disease control efficacy compared to un-sprayed control.

\section{Conclusions}

In the present investigation, an attempt was made to isolate and screen the native Pseudomonas spp. with better antagonistic and phosphate solubilising potentials in vitro against soil and tuber-borne diseases of potato. The isolate Pf14 showed a strong inhibitory action against R. solani, S. sclerotiorum, S. rolfsii and Fusarium spp. and was able to produce various antagonistic metabolites, including antifungal volatile compounds (VOCs), as well as it showed a good phosphorus solubilising potential. Under field conditions, talc based formulation of Pf14 showed better growth enhancement potentials and decreased black scurf severity. The findings suggested that the selected bacterial isolate Pf14 had the ability to be used as bioagent and biofertilizer in the integrated disease management programme of major potato diseases.

\section{Abbreviations}

PDA: Potato dextrose agar; NB: Nutrients broth; PSI: Phosphate solubilisation index; VCs: Volatile compounds; t/ha: Tonnes per hectare; ICAR: Indian Council of Agricultural Research; RBD: Randomized block design.

\section{Acknowledgements}

The present work is based upon research supported by the research grant (EEQ/2016/000298) of the Science and Engineering Research Board (SERB)Department of Science and Technology (DST), Government of India

\section{Authors' contributions}

ML, AK and SC had conducted the experiments. ML and SC prepared draft of Manuscript. MK, SS and RK edited the manuscript. All authors have read and approved the manuscript.

\section{Funding}

The present work is based upon research supported by the research grant (EEQ/2016/000298) of the Science and Engineering Research Board (SERB)Department of Science and Technology (DST), Government of India.

Availability of data and materials

Not applicable.

\section{Declarations}

Ethics approval and consent to participate

Not applicable.

Consent for publication

Not applicable.

\section{Competing interests}

The authors declare that they have no competing interests.

\section{Author details}

${ }^{1}$ Division of Plant Protection, ICAR-Central Potato Research Institute, Regional Station Modipuram, Meerut, Uttar Pradesh 250 110, India. ${ }^{2}$ Division of Crop Improvement, ICAR-Central Potato Research Institute Station, Patna, , Bihar 801 506, India. ${ }^{3}$ Division of Plant Protection, ICAR-Central Potato Research Institute, Shimla, Himachal Pradesh 170 001, India. ${ }^{4}$ ICAR-Central Potato Research Institute, Regional Station Modipuram, Meerut, Uttar Pradesh 250 110, India.

Received: 8 October 2021 Accepted: 27 February 2022

Published online: 07 March 2022

\section{References}

Apaliya MT, Zhang HY, Zheng XF, Yang QY, Mahunu GK, Kwaw E (2017) Exogenous trehalose enhanced the biocontrol efficacy of Hanseniaspora uvarum against grape berry rots caused by Aspergillus tubingensis and Penicillium commune. J Sci Food Agric 98:4665-4672

Bakker PAHM, Pieterse CMJ, LoonLC V (2007) Induced systemic resistance by fluorescent Pseudomonas spp. Phytopathology 97:239-243

Bautista G, Mendoza H, Uribe D (2007) Biocontrol of Rhizoctonia solani in native potato (Solanum phureja) plants using native Pseudomonas fluorescens. Acta Biol Colomb 12:19-32

Bertrand H, Nalin R, Bally R, Marel JCC (2001) Isolation and identification of the most efficient plant growth promoting bacteria associated with canola. Biol Fert Soil 33:152-156

Caulier S, Gillis A, Colau G, Licciardi F, Liépin M, Desoignies N, Modrie P, Legrève A, Mahillon J, Bragard C (2018) Versatile antagonistic activities of soilborne Bacillus spp. and Pseudomonas spp. against Phytophthora infestans and other potato pathogens. Front Microbiol 9:143 
Chaudhary S, Sagar S, Lal M, Tomar A, Kumar V, Kumar M (2020a) Biocontrol and growth enhancement potential of Trichoderma spp. against Rhizoctonia solani causing sheath blight disease in rice. J Environ Biol 41:1034-1045

Chaudhary S, Lal M, Sagar S, Tyagi H, Kumar M, Sharma S, Chakrabarti SK (2020b) Genetic diversity studies based on morpho-pathological and molecular variability of the Sclerotinia sclerotiorum population infecting potato (Solanum tuberosum L.). World J Microbiol Biotechnol 36:177

Clarkson J, Whipps J (2002) Control of sclerotial pathogens in horticulture. Pestic Outlook 13:97-101

Daami-Remadi M, Jobnoun-Khiareddine H, Sdiri A, El Mahjoub M (2010) Comparative reaction of potato cultivars to Sclerotinia rolfsii assessed by stem rot and tuber decay severity. Pest Technol 6:54-59

De Vrieze M, Germanier F, Vuille N, Weisskopf L (2018) Combining different potato-associated Pseudomonas strains for improved biocontrol of Phytophthora infestans. Front Microbiol 9:2573

DeBritto S, Gajbar TD, Satapute P, Sundaram L, Lakshmikantha RY, Jogaiah S, Ito S (2020) Isolation and characterization of nutrient dependent pyocyanin from Pseudomonas aeruginosa and its dye and agrochemical properties. Sci Rep 10:1542

Dukare AS, Paul S, Nambi VE, Gupta RK, Singh R, Vishwakarma RK (2019) Exploitation of microbial antagonists for the control of postharvest diseases of fruits: a review. Crit Rev Food Sci 59(9):1498-1513

Edi-Premono ME, Moawad MA, Vleck LG (1996) Effect of phosphate solubilizing Pseudomonas putida on the growth of maize and its survival in the rhizosphere. Indones J Crop Sci 11:13-23

El-Komy HMA (2005) Coimmobilization of Azospirillum lipoferum and Bacillus megaterium for successful phosphorus and nitrogen nutrition of wheat plants. Food Technol Biotechnol 43(1):19-27

Ghods-Alavi BS, Ahmadzadeh M, Behboudi K, Jamali S (2012) Biocontrol of rhizome soft rot (Pectobacterium carotovorum) on valerian by Pseudomonas spp. under in vitro and greenhouse conditions. J of Agric Techno 8:1913-1923

Glare T, Caradus J, Gelernter W, Jackson T, Keyhani N, Köhl J (2012) Have bio pesticides come of age? TrendsBiotechnol 30(5):250-258

Harrigan WF, MacCance ME (1976) Laboratory methods in food and dairy microbiology. Academic Press, London

Hucker GJ, Conn HJ (1923) Methods of gram staining. Technical. Bulletin of the New York state, Agriculture Experimental Station, p 93

Islam MA, Nain Z, Alam MK, Banu NA, Islam MR (2018) In vitro study of biocontrol potential of rhizospheric Pseudomonas aeruginosa against Fusarium oxysporum f. sp. cucumerinum. Egypt J Biol Pest Control 28:90

Ji SH, Gururani MA, Chun SC (2014) Isolation and characterization of plant growth promoting endophytic diazotrophic bacteria from Korean rice cultivars. Microbiol Res 169:83-98

Ji SN, Paul NC, Deng JX, Kim YS, Yun B, Yu SH (2013) Biocontrol activity of Bacillus amyloliquefaciens CNU114001 against fungal plant diseases. Mycobiology 41:234-242

Kang SM, Radhakrishnan R, Lee IJ (2015) Bacillus amyloliquefaciens subsp. plantarum GR53, a potent biocontrol agent resists Rhizoctonia disease on Chinese cabbage through hormonal and antioxidants regulation. World J Microb Biot 31:1517-1527

Lal M, Chaudhary S, Yadav S, Sharma S, Chakrabarti SK, Kumar M (2019) Development of spray schedules for management of late blight of potato using new chemicals. J Mycol PI Pathol 49(4):405-412

Lal M, Chaudhry S, Rawal S, Sharma S, Kumar M, Chakrabarti SK (2021) Evaluation of bio-agents and neem based products against late blight disease (Phytophthora infestans) of potato. Indian Phytopathol 74(1):181-187

Lal M, Singh AP, Tomar S, Hussain T, Sharma S, Kaushik SK, Singh BP (2013) Antagonistic effect of bio-agents against three potato fungal diseases and their fungicidal sensitivity. Vegetos 26:362-367

Lee T, Park D, Kim K, Lim SM, Yu NH, Kim S, Kim HY, Jung KS, Jang JY, Park JC, Ham H, Lee S, Hong SK, Kim JC (2017) Characterization of Bacillus amyloliquefaciens DA12 showing potent antifungal activity against mycotoxigenic Fusarium species. Plant Pathol J 33:499-507

Mrabet M, Elkahoui S, Tarhouni B, Djebali N (2015) Potato seed dressing with Pseudomonas aeruginosa strain RZ9 enhances yield and reduces black scurf. Phytopathol Mediterr 54(2):265-274

Ommati F, Sharifi K (2008) Determination of species and dispersal of potato Fusarium wilt in Semnan province. In: Proceedings of the 18th Iranian plant protection congress, 24-27 Aug 2008, Hamadan, Iran, p 70
Raza W, Ling N, Liu D, Wei Z, Huang Q, Shen Q (2016) Volatile organic compounds produced by Pseudomonas fluorescens WR-1 restrict the growth and virulence traits of Ralstonia solanacearum. Microbiol Res 192:103-113

Sagar V, Sharma S, Jeevalatha A, Chakrabarti SK, Singh BP (2011) First report of Fusarium sambucinum causing dry rot of potato in India. New Dis Rep 24:5

Stanier RY, Palleroni NJ, Doudoroff M (1966) The aerobic pseudomonads: a taxonomic study. J Gen Microbiol 43:159-271

Sundin G, Werner NA, Yoder KS, Aldinckle HS (2009) Field evaluation of biological control of fire blight in the eastern United States. Plant Dis 93:386-394

Tomer S, Suyal DC, Shukla A, Rajwar J, Yadav A, Shouche Y, Goel R (2017) Isolation and characterization of phosphate solubilising bacteria from Western Indian Himalayan soils. 3 Biotech 7:95

Tripathi M, Johri BN (2002) In vitro antagonistic potential of fluorescent Pseudomonas and control of sheath blight of maize caused by Rhizoctonia solani. Ind J Microbiol 42:207-214

Trivedi P, Pandey A, Palni LMS (2008) In vitro evaluation of antagonistic properties of Pseudomonas corrugata. Microbiol Res 163:329-336

Tsror L (2010) Biology, epidemiology and management of Rhizoctonia solani on potato. Jof Phytopath 158:649-658

Vining LC (1990) Functions of secondary metabolites. Annu Rev Microbiol 44:395-427

Wallace RL, Hirkala DL, Nelson LM (2018) Mechanisms of action of three isolates of Pseudomonas fluorescens active against postharvest grey mold decay of apple during commercial storage. Biol Control 117:13-20

Wang X, Wang C, Ji C, Li Q, Zhang J, Song X, Liu XL (2018) Isolation and characterization of antagonistic bacteria with the potential for biocontrol of soil-borne wheat diseases. J Appl Microbiol 125:1868-1880

Whittenbury R (1964) Hydrogen peroxideformation and catalase activity in the lactic acid bacteria. J Gen Microbiol 35:13

Zhai Y, Shao Z, Cai M, Zheng L, Li G, Huang D, Cheng W, Thomashow LS, Weller DM, Yu Z, Zhang J (2018) Multiple modes of nematode control by volatiles of Pseudomonas putita 1 A00316 from Antarctic soil against Meloidogyne incognita. Front Microbio 9:253

\section{Publisher's Note}

Springer Nature remains neutral with regard to jurisdictional claims in published maps and institutional affiliations.

\section{Submit your manuscript to a SpringerOpen ${ }^{\circ}$ journal and benefit from:}

- Convenient online submission

- Rigorous peer review

- Open access: articles freely available online

- High visibility within the field

Retaining the copyright to your article

Submit your next manuscript at $>$ springeropen.com 